\title{
An Analysis of Research on Constructivist Teacher Education
}

\author{
Julie Rainer Dangel
}

Georgia State University

\begin{abstract}
This review of research (1990 to 2009) on constructivist teacher education synthesizes a growing but fragmented body of research and links it to practice in teacher education; it provides a guide for future research, program development, and policy and practice development which is consistent with empirical evidence. It includes a selection of 27 studies on preservice efforts; efforts which include programs, courses, and field experiences. First, an analysis of the research suggests a variety of effects from both short- and long-term experiences. Effects are identified in two categories: (a) conceptual understandings (with three subcategories: understanding of content, pedagogy, and the self as learner) and (b) classroom practice. Then, based on the findings, six mediatory experiences are suggested that facilitate preservice teachers' growth. Finally, the studies are assessed using a framework (Darling Hammond, 2006) to determine gaps in the research.
\end{abstract}

Keywords: constructivism; Teacher Education; preservice teachers 


\section{An Analysis of Research on Constructivist Teacher Education}

Tellez (2007), in reviewing major reform efforts, finds that the "importance of constructivism in educational theory and research cannot be underestimated" (p. 553); however, he questions its impact on educational practice. While there are many reasons for this, I wondered if one reason might be the lack of a coherent research base. Given the continuing interest and number of programs grounded in constructivist theories (Beck \& Kosnik, 2006; Rainer, 2002; Richardson, 1997), I believe it is time to acknowledge the role of theory and investigate the impact of constructivist teacher education on preservice teachers. Based on the importance of ongoing examination of research, my interests in knowing more about constructivist teacher education, and the growing number of studies of programs, my goals are to (a) identify and analyze substantive research on constructivist teacher education, (b) synthesize the effects of constructivist teacher education efforts on preservice teachers, (c) determine which efforts facilitate understanding and practice of constructivist pedagogy, and (d) assess the research for its contribution to teacher education reform. This review has scholarly significance in synthesizing a growing but fragmented body of research and linking it to practice in teacher education; it has practical significance for guiding future research and program development and assisting in policy and practice development that is consistent with empirical evidence.

The concept of an educational research review has undergone a transformation over the last decade. This change encompasses major facets of a review, including the role of the author, the selection, and methodology of research studies within the review, and the review's use within the educational community. Whereas a review, formerly, was considered a synthesis of published research within a field of inquiry, now it is recognized as having a more dynamic and interactive role in the creation and development of what researchers and practitioners know about an educational topic. In this review, I am positioned as a teacher educator with experience in constructivist teacher education but I also want to know more about the work of others. The details related to the findings can inform and extend my research, as well as that of other teacher educators. Our programs and my practice will benefit from a synthesis of the effects others have found. Thus, the purpose of this review is, as Lather (1999) describes, "a way of knowing", and I use writing as a method of inquiry (p. 4).

\section{Prior Reviews and Studies Informing this Review}

In the absence of prior reviews of constructivist teacher education, I began with reviews and studies by Wideen, Mayer-Smith, and Moon (1998) and Tatto (1998) on the effects of preservice teacher education programs on teachers' beliefs and understandings. These provided a beginning point for exploration of the effects and a foundation and impetus for this review.

Studies of preservice teacher education reviewed by Wideen et al. (1998) led them to conclude that teacher educators needed to "ground the process of learning to teach within a theory that is radically different from that which has traditionally underpinned research and programs in teacher education" (p. 167). They suggested that learning to teach was a deeply personal activity and that programs needed to encourage beginning teachers to examine their prior beliefs and engage in a process of negotiating a teaching role that incorporated effective practice, a perspective consistent with a view of beginning teachers constructing their own knowledge. Wideen et al. (1998) further suggested that there was "little evidence to support an approach to learning to teach which focuses primarily on the provision of propositional knowledge" (p. 160). Tatto (1998) investigated the hypothesis that "constructivist-oriented 
teacher education... will have more influence on teacher education students' views than conventionally oriented teacher education" (p.67). She examined data (questionnaire, interview and observation) from eight preservice and in-service programs (four conventional and four constructivist teacher education programs). For her study, a conventional program was one that prepared teachers to fit into existing school structures, teach knowledge as separate from practice, and view pupils as passive recipients of knowledge. Data indicated that conventional programs created teachers who espoused conventional or unchanged ideas. Data from three constructivist programs suggested they were successful in "helping experienced teachers transform their role" and had a "high impact upon teaching practices" (Tatto, 1998, p.76). These bodies of work, indicating that constructivist teacher education may be more influential on preservice teachers than conventional programs, were consistent with Wood (1995) who suggested that "the alternative perspective that constructivism offers by defining learning as a process of personal construction of meaning offers a potentially powerful way to rethink teacher education" (p. 336).

\section{Research Questions}

With the knowledge offered in previous reviews and studies, I sought answers to questions influencing the work of many teacher educators. What are the effects of constructivist teacher education on preservice teachers' thinking and classroom practice? What facilitates preservice teachers' understanding of constructivist theories and classroom practice?

\section{Methodology for Review: Selection and Review Process}

Using multiple electronic databases (e.g., Ebscohost, ERIC), I selected journal articles, edited books, and conference presentations from 1990 to 2009. Citations in these documents provided references to other studies to consider. This body of knowledge included program descriptions, position papers, and research studies that addressed constructivist teacher education; only research was included in this synthesis. There were two criteria for inclusion in this review: (a) the relationship of the teacher education effort to constructivist theories and (b) the quality of the research.

A complication was the variety of terminology associated with constructivist theories and constructivist practice (Fosnot, 1996; Richardson, 1997). Richardson (1997) suggested that there were common understandings and considerable disagreements and that the "extent of agreement" (p. 3) on a definition for constructivism was as a theory of meaning making. A second complication was to define constructivism as related specifically to teacher education.

In order to focus specifically on teacher education and ensure consistency, I selected studies that fit the explanation of constructivist teacher education (Rainer, 2002), which identifies the following seven dimensions: learning and development; authority and facilitation; action and reflection; autonomy and community; process and content; power and empowerment; and critical thinking and multiple perspectives. For example, in identifying a constructivist program or course, I would look for elements that included the importance of content in the teacher education but also an emphasis on process.

While there were many teacher education programs that considered themselves constructivist, (a search using constructivist programs elicited hundreds of references) or focused on elements that often were considered constructivist, such as learner-centered or reflective practice, only those explicitly grounded in constructivist theories were considered for this 
review. Richardson (1997) suggested there were two different forms of constructivist teacher education: (a) teaching teachers about constructivist approaches and (b) working with students in a constructivist way to help them understand their tacit beliefs and introduce new conceptions as possible alternatives those held. I selected studies that represented the second form of Richardson's definition.

After compiling the studies, I sent a request to respected authors of work in constructivism and education, identified through the Association for Constructivist Teachings and the AERA SIG on Constructivist Theory (American Educational Research Association Special Interest Group), for their suggestions for inclusion. While many authors wrote conceptually about constructivist teacher education, no new studies surfaced.

The second criterion for selection was the quality of the research. Each report had to contain sufficient, relevant information to determine the quality of the methodology and sufficient support for conclusions. All were peer-reviewed and evidence-based. I summarized each study using a template that included the following categories: focus of study, participants, role of the researcher, data collection and analytic methods, and substantive results. As most studies were qualitative, I used criteria for quality suggested by Lincoln and Guba (1985). From 41 documents of preservice efforts, 27 studies were selected for this review.

I approached the review process inductively allowing themes to emerge from data. An initial analysis included descriptive categories such as short- and long-term interventions. From a deeper level of analysis, a more focused look at the effects of programs on conceptual understanding and classroom practice emerged. The findings that follow are organized by research question.

\section{What are the Effects of Constructivist Teacher Education on Preservice Teachers?}

To answer this question I analyzed the 27 studies (See Table 1 for details) of preservice constructivist teacher education efforts; 19 described long-term interventions (defined as programs for initial certification of at least one year in length) and eight described short-term interventions (defined as projects, courses, or semester long field experiences). There were 16 studies in early childhood/elementary education, two in middle grades, eight in a secondary education, and one in a K-12 context. Researchers examined efforts in 19 institutions in the United States and eight in international settings. There were 19 qualitative studies making it a rich and complex body of literature.

A synthesis of this research (both short- and long-term interventions) suggested two major effects: (a) change in teacher candidates' conceptual understanding of content, constructivism, and constructivist pedagogy, and/or (b) change in teacher candidates' implementation of constructivist pedagogy in classrooms. In the following sections, I provide an overview of the studies followed by an analysis of the two major effects, first for short-term efforts and then for long-term efforts.

\section{The Potential Effects of Short-Term, Preservice, Constructivist Teacher Education Efforts}

There were eight studies that provided findings on the effects of short-term, preservice, constructivist, teacher education efforts; all were studies of courses and/or field experiences. There were five qualitative studies, using data such as interviews, classroom observation, reflective papers, field-logs or journals, and lesson plans, and two studies used mixed-methods. One study (Steele, 1994) utilized a standardized questionnaire and a pre-post design. In four of 
the studies in this category, teacher-learners were observed or videotaped in their field placements and Chen (2001) and Sherman and MacDonald (2007) followed up with preservice teachers as they continued in the program. The purpose of the research, overall, was to evaluate the effects of constructivist teacher education practices on preservice teachers' conceptual understandings and the extent to which they implemented teaching practices reflective of a constructivist perspective.

Impact on teacher candidates' conceptual understanding. The potential effects of short-term constructivist efforts on preservice teachers' conceptual understandings are categorized in three areas: beliefs and understandings of content, understanding of constructivist pedagogy, and understanding self as a learner.

Beliefs and understandings of content. Findings from five studies showed potential effects related to beliefs and understandings of content. Mayer-Smith and Mitchell (1997) identified individuals on a continuum of change from deeply influenced to limited understanding of constructivist practice. Preservice teachers (6 of 16) in the deeply influenced category demonstrated espoused beliefs and understandings consistent with constructivist ideas. There were five participants who frequently took a constructivist perspective but lacked the coherency of the first group; four students accepted parts of the course but others were ignored; and one teacher demonstrated minimal understanding or acceptance.

Related to content, Steele (1994) found that a majority of preservice teachers began to question traditional views of what it means to know mathematics and came to recognize that there was not just one way to do math. Preservice teachers in studies by Dhindsa and Anderson (2004), Sherman and MacDonald (2007), and Stofflet and Stoddart (1994) significantly improved their scientific content knowledge. For example, Dhindsa and Anderson found preservice chemistry teachers were able to: (a) access new knowledge and elaborate on existing knowledge or both, (b) reconstruct their knowledge around large organizing ideas, and (c) carefully structure their logical arguments. They also increased the interconnectedness of their ideas.

Understanding of constructivist pedagogy. In six of eight studies, authors found that short-term interventions had an impact on teacher candidates' pedagogical understanding. In the Mayer-Smith and Mitchell (1997) study, most (13 of the 16) preservice teachers were able to distinguish didactic from learner-centered teaching approaches and demonstrated a familiarity with teaching for understanding. They also viewed teachers' and pupils' questions as essential to promote and challenge thinking, increase motivation, relate content to pupils' interests and experiences, and examine pupils' understandings. In Jadallah's (1996) study, preservice teachers were able to relate pupil motivation to "the extent a lesson promoted active participation, subject matter which caused students to experience cognitive dissonance, and subject matter which related to students' past experiences" (p.78). Likewise, preservice teachers reported the importance of active involvement in reconstructing knowledge and recognized the need to tailor communication to meet the needs of learners (Dhindsa \& Anderson, 2004). Both Steele (1994) and Chen (2001) found that prospective teachers increased their understanding of constructivist pedagogical strategies and the importance of establishing a supportive and risk-free climate for learning. Steele also found a significant difference in means with post-test scores indicating preservice teachers' beliefs favored constructivist pedagogy. Stofflet and Stoddart (1994) found that preservice teachers in an elementary science methods course gave qualitatively stronger pedagogical responses and provided conceptually-based rationales for their pedagogy. They 
wrote lesson plans that demonstrated coherent understandings of constructivist pedagogy including less reliance on textbooks and worksheets in instruction.

Understanding of self as learner. To a lesser extent, the short-term efforts promoted change in the area of teacher candidates acquiring constructivist learning behaviors for themselves. There were findings from three studies (Chen, 2001; Duran, McArthur, \& Van Hook, 2004; Steele, 1994) related to how prospective teachers think about themselves as learners. Chen identified several areas of growth for preservice teachers: acquiring positive learning behaviors and attitudes, developing collaborative and active learning habits, learning to appreciate different ways of thinking, and enhancing their capability and sensitivity in reflection. Duran et al. found that prospective middle-grade teachers not only recognized constructivist methods as helpful for their own learning and developed an appreciation for inquiry-based methodology, but also identified personal tension and conflict in constructivist courses. These students, as well as students in the Sherman and MacDonald (2007) study, recognized their need for relevant science content knowledge.

The impact on teacher candidates' classroom practice. A second category of effects identified in short-term studies was impact on classroom practice. There were four studies that included analysis of practice. Jadallah (1996) used videotapes to investigate preservice teachers' practice in the field and found they taught lessons based on pupil's interests and involved children in experiential learning and guided discovery lessons. They introduced subject matter that caused pupils to experience cognitive dissonance in their learning and included higher-order thinking in their lessons. They also encouraged active involvement of pupils in lessons. Likewise, Stofflet and Stoddart (1994) and Chen (2001) found preservice teachers used constructivist pedagogy more consistently in practice, e.g., guided discovery activities and experimentation, a reduced amount of lecturing and increased questioning, and opportunities for children to discuss their ideas. In observing preservice teachers during their field placements, Mayer-Smith and Mitchell (1997) noticed that preservice teachers experimented with a range of constructivist strategies in their teaching, including probing the prior views of pupils, incorporating in-depth discussions, having pupils examine their beliefs, and using role-play.

\section{The Potential Effects of Long-Term, Preservice, Constructivist Teacher Education Efforts}

Researchers examined the effects of 19 long-term programmatic efforts on preservice teachers; all efforts were of at least one year in length. The qualitative studies used data such as group and individual interviews conducted over time, classroom observations, portfolios, dialogue journals, questionnaires, course evaluations, college course syllabi, and program documentation. The quantitative studies used pre-post design and a variety of instruments. The purpose of the studies overall was to gain insights into the development of preservice teachers, explore their experiences in programs, and study the process of change.

The impact on teacher candidates' conceptual understanding. Studies suggested that long-term interventions had an impact on teacher candidates' conceptual understanding similar to that of short-term efforts. The same areas of change used to categorize short-term efforts are useful here: (a) developing beliefs and understanding of content, (b) understanding constructivist pedagogy, and (c) understanding self as a learner.

Beliefs and understanding of content. In terms of subject matter, Hand and Peterson (1995) and Luera and Otto (2005) found that preservice teachers changed their views on teaching and learning science and increased their understanding of science topics. Fosnot (1996) found 
that preservice teachers broadened their definitions of mathematics. Luera and Otto did note that more than one course was needed to make a significant difference. Authors of two studies (Graham, Hudson-Ross \& McWhorter, 1997; Gunstone, Slattery, Baird, \& Northfield, 1993) discussed preservice teachers' growth in terms of their overall intellectual development. For example, Gunstone et al. (1993) stated,

The most striking findings from the year related to the nature and extent of personal development experienced by many of the participants. This development was in individual intellectual competence (attitudes, perceptions, conceptions, and abilities), and... of two major types: in specific task-related competencies and in more general aspects of intellectual competence. (p.67)

Other authors (Al-Weher, 2004; Andersen \& Piazza, 1996; Black \& Ammon, 1992; Cheng, Chan, Tang, \& Cheng, 2009; Graham et al., 1997, Lesar, Benner, \& Habel, 1996) found increased understanding of the theoretical underpinnings of constructivism and changes in epistemological beliefs. In a quantitative study, Al-Weher (2004) found a significant difference between experimental and control groups' beliefs about constructivist teaching and learning, and more specifically, that females' perceptions were more consistent with constructivist ideas than males. In qualitative studies, Cheng et al. (2009) determined that preservice students came to believe that knowledge was constructed in context and was constantly changing and Graham et al. (1997) established that preservice teachers developed a strong theoretical grounding for teaching in a more holistic and integrative way. These results are important given Fosnot's (1996) finding that being able to provide a theoretical rationale for pedagogy is a critical element for teachers to implement constructivist practice.

Understanding of constructivist pedagogy. All of the studies of long-term efforts provided findings related to student's enhanced pedagogical understanding. This research showed preservice teachers reported increasing (a) their skills to develop classroom community (Beck \& Kosnik, 2001), (b) their views of learner-centeredness as essential to teaching (Condon, Clyde, Kyle, \& Hovda, 1993; Graham et al., 1997), (c) their use of inquiry-based teaching approaches (Marek, Laubach, \& Pederson, 2003), and (d) their ability to set up learning environments for children to take responsibility for learning (Levin, 2003). Related to learnercentered instruction, Fosnot (1996) found that preservice teachers realized the importance of active, in-depth learning where children collaborated and took ownership for their learning. These same preservice teachers expanded their views of teachers' roles to include providing support, guidance, and probing questions to encourage children's investigations. Andersen and Piazza (1996) found that preservice teachers developed beliefs about mathematics pedagogy that included (a) the importance of physical models for enhanced learning, (b) the use of group work and student discussion, (c) the importance of mathematics making sense, and (d) viewing learning and solving problems as happening in diverse ways.

In three studies of the Developmental Teacher Education (DTE) Program, Black and Ammon (1992), Kroll and Black (1993), and Levin (2003) provided evidence of increased pedagogical understanding. For example, in a follow up of DTE graduates, Levin found that teachers (a) understood how to facilitate pupils' learning and how to purposefully set up the learning environment, (b) understood that children need to resolve their own disequilibrium and (c) saw the importance of the academic and social worlds of children. More detail on how these pedagogical understandings were implemented is provided in the section on the impact on classroom practice. 
Understanding of Self as Learner. Findings from eight studies indicated that long-term efforts promoted change in preservice teachers' understandings of themselves as learners. Preservice teachers came to believe that, because the learner was an important part of the learning process, they themselves had an expanded role in their learning (Fosnot, 1996; Kilgore \& Ross, 1993). Lesar et al. (1996) concluded that constructivist approaches opened up new ways of learning and knowing for preservice teachers and Gunstone et al. (1993) documented effects on preservice teachers' personal awareness, sense of self, and professional purpose. Likewise, Beck and Kosnik (2001), focusing specifically on the effects of community, found evidence of risk-taking, inclusiveness, confidence, leadership, and professional growth. Graham et al. (1997) and Condon et al. (1993) found that preservice teachers deepened their understandings of themselves as learners through classroom inquiry and both studies reported that preservice teachers re-negotiated new meanings for themselves as learners and professionals. Finally, Anderson and Piazza (1996) investigated preservice teachers' affective thinking related to constructivist mathematics pedagogy and found preservice teachers were more confident, enjoyed learning, valued others' ideas, and felt they had something to contribute to the learning process.

The impact on teacher candidates' classroom practice. There were five studies of long-term efforts (Kroll \& Black, 1993; Levin, 2003; Magliaro, Murphy, Sawyers, Atlieri \& Nienkark, 1996; and Parsons-Chatman, 1990; Tillema, 2000) that included observations of preservice teachers' performance. Of these five, three studies (Kroll \& Black, 1993; Levin, 2003; Tillema, 2000) identified effects on teacher candidates' classroom practice and two studies (Magliaro et al., 1996; Parsons-Chatman, 1990) focused on the process of change for preservice teachers. Kroll and Black (1993) compared traditionally trained teachers to DTE graduates and found the DTE graduates used more, small, heterogeneous groupings; offered children more choice in content and groupings; provided pupils with reasons for engaging content, and focused on both the content and process of learning. In the area of math and literacy, graduates of both traditional programs and the DTE program used physical models and basal readers; however, DTE graduates used physical models more centrally in instruction and basal readers more as a supplement to children's literature and trade books. The two groups used different methods of assessing pupils with the DTE graduates using teacher observation and performance tasks as primary data for making assessments.

In summary, the work presented above suggests that courses, field experiences, and programs that model constructivist pedagogy have effects on teacher candidates' conceptual understanding (beliefs, content, constructivist pedagogy, and self as learner) and classroom practice. This provides a place to begin answering Virginia Richardson's (2003) question, "What does constructivist teaching do for students that is different from their learning within a traditional transmission model?" The detailed list of findings (see Table 2 ), summarizing the potential cognitive, affective, and performance-based outcomes for the constructivist teacher education efforts identified in the review, indicates what we can expect using a constructivist approach. To date, there has not been a comprehensive synthesis of the effects of constructivist approaches. These findings offer potential measures for examination for program development and future research. Researchers may use the findings to compare the effects of constructivist programs to the effects of traditional programs. For example, do students from traditional programs take a view of themselves as learners as found by Kilgore and Ross (1993)? Program developers (including teacher educators) may examine the findings and ask themselves, is this the kind of outcomes we want to see in our preservice teachers? For example, do we want 
teachers who are able to introduce subject matter which causes children to experience cognitive dissonance and involve children in experiential learning, as found by Jadallah (1996)?

\section{What Efforts Facilitate and Constrain Constructivist Theory and Pedagogy?}

In answering the second research question, I discovered that the research on constructivist teacher education included findings and discussion on what facilitated teacher development. Analysis of these findings suggested six key mediatory experiences for preservice teachers: social interaction, meaningful learning experiences, ownership, reflection, developing a personal theory of learning, and a supportive environment. This research offers some direction for what needs to occur in teacher preparation programs to enable a shift of beliefs, understandings and practice.

\section{Key Mediatory Experiences for Preservice Teachers}

Social interaction. Social interaction and collaboration played a strong role in constructivist theories and programs based on its principles. Several authors (A1-Weher, 2004; Fosnot, 1996; Graham et al., 1997; Gunstone et al., 1993; Jadallah, 1996; Magliaro et al., 1996; Sherman \& MacDonald, 2007) suggested that collegiality, social interaction and the use of discourse were key experiences for preservice teachers and teacher educators. Sherman and MacDonald (2007) found that collaborative opportunities provided a "level of trust that encouraged students to take risks in their learning" (p. 531). Parsons-Chatman (1990), Al-Weher (2004), Graham et al. (1997), and Gunstone et al. (1993) concluded that peer discussions, collaborative group activities, and strong personal and professional relationships were also critical elements. Specific recommendations were made by Fosnot (1996) and Beck and Kosnik (2001) for cohorts groups and learning communities to encourage social interaction.

Meaningful learning experiences. Meaningful learning experiences referred to opportunities to connect conceptual understanding to classroom practice. Examples include inquiry projects, problem-based learning, reflection and relevant field experiences for preservice teachers. Chen (2001) and Tillema (2000) identified situated learning experiences as one of the factors that influenced construction of beliefs and constructivist practice; however, reflection on their experience was critical. Jadallah (1996) and Fosnot (1996) suggested that if preservice teachers were to construct knowledge from their experiences and social interactions, then collaborative learning experiences that allowed for investigation and experimentation were critical in facilitating constructivist teaching. Fosnot suggested that teachers' beliefs needed to be illuminated, discussed, and challenged in light of classroom practice. Fosnot further suggested school partnerships that support an integrated, learner-centered approach to curriculum as one way to provide the supportive environment that Mayer- Smith and Mitchell (1997) found as essential. Gunstone et al. (1993) found that meaningful experiences reassured preservice teachers about their choice of a profession, clarified areas for improvement, and generated personal meaning for learning. Research also documented two constraints to meaningful learning experiences: lack of support in practicum settings (Al-Weher, 2004; Parsons-Chatman, 1990) and the performance for grades approach that takes place in many university courses (ParsonsChatman, 1990).

Ownership. Many studies described constructs (autonomy, voice, personal relevance, and empowerment) that I termed ownership. Condon et al. (1993) recommended role redefinitions (for teacher educators and prospective teachers) where both take more active roles as learners. Fosnot (1996) and Gunstone et al. (1993) found the importance of empowerment in 
teachers developing personal and relevant ideas about their learning and how others learn. Kroll and Black (1993) suggested the importance of providing teachers with a strong enough grounding in developmental theory and research (including linkages between developmental constructs and teaching methods) to make them autonomous professionals and decision makers about what and how to teach. They concluded that an approach based on developmental theory provided a way to think differently about teacher education-as preparation that empowers teachers. This notion of shared ownership, congruent with Richardson's (1997) argument that constructivist teacher education requires "radically altering power relationships" (p. 11), facilitated new understandings.

Reflection. Al-Weher (2004), Chen (2001), Fosnot (1996), and Jadallah (1996) found reflection to facilitate conceptual understanding and constructivist practice. Jadallah (1996) concluded, "Knowledge about teaching and learning is constructed and reconstructed through the reflective analysis of experiences" (p. 83). Most often, authors Fosnot, 1996; Jadallah, 1996; Kroll and Black, 1993) cited reflection as a strategy to analyze and confront individual's thinking and create a personal theory of teaching and learning. Interestingly, Tillema (2000) identified a dynamic relationship between reflection and meaningful field experience and suggested that reflection after immersion in practice was more productive for effecting changes in belief than reflection before practice. These findings were consistent with Mosenthall and Ball (1992) who suggested the importance of the relationship between deep content and good teaching through reflection.

Developing a personal theory of teaching and learning. The research suggested that a central feature of constructivist programs was to encourage teacher learners to understand constructivism and develop their own theories of learning as a basis for making instructional decisions. Plourde and Alawiye (2003) found a positive relationship between student teachers' knowledge of constructivism and their anticipated use of constructivist pedagogy in the classroom. According to Fosnot (1996), teacher-learners needed to examine their beliefs and reflect on their practice in light of constructivist theories and then develop their own theories of learning. Her research supported teachers' development of their own epistemological views enabling them to make decisions informed by their professional judgment. Both Jadallah (1996) and Fosnot found preservice teachers who were able to go beyond conceptual labels and clearly explain their reasoning for using particular instructional practices were more likely to develop and implement lessons consistent with constructivist conceptual understandings.

Supportive environment. Many authors (Condon et al., 1993; Fosnot, 1996; Lesar et al., 1996; Mayer-Smith \& Mitchell, 1997; Parsons-Chatman, 1990) suggested the importance of a supportive environment for teacher-learners as they reconstruct their ideas and practice. Their recommendations for a supportive environment included ideas such as learning communities, cohort groups, respectful relationships between faculty and students, democratic practices, partnerships for quality field experiences, mentor programs for first year teachers, and sharing theoretical issues and pedagogical practices with supervising and cooperating teachers. Beck and Kosnik (2001) found positive effects of a learning community approach and Chen (2001) identified supportive feedback, encouragement, openness to new ideas, and a positive climate as key factors that influence the practice of a constructivist approach. Gunstone et al. (1993) confirmed the importance of supporting preservice teachers' affective, as well as cognitive needs in learning. In order to sustain changes, O'Loughlin (1992) provided a clear imperative for teacher educators as they engaged teachers in constructivist processes. He concluded that we 
have an obligation to support them in confronting the challenges and political changes necessary to rethink their teaching practice.

While these six key mediatory experiences are presented separately for clarity, they are components of a larger, more complex picture. No program relies on any single practice. These key mediatory experiences, along with common elements of constructivist teacher education programs (Rainer Dangel \& Guyton, 2004), suggest possibilities for restructuring teacher education programs.

\section{Challenges for Constructivist, Preservice Teacher Education}

As teacher educators, we cannot ignore the challenges. The reality of constructivist teacher education is that it functions in a university setting and this traditional context provides challenges for teacher educators and teachers (Rainer \& Guyton, 1999; Beck \& Kosnik, 2006). While studies reviewed did not directly address the factors that constrained their work, authors made recommendations based on their experience. Condon et al. (1993) found that "simply accommodating innovation in the existing institutional structure will not provide the long-term support necessary for lasting change." Two authors (Condon, et al., 1993; Chen, 2001) recommended areas that need to be challenged if this work is to continue, including, traditional teacher and student roles, rewards, resources, policies, and the history of isolation in higher education. Teacher educators who advocate for a different kind of preparation cannot overlook their own pedagogy, particularly related to authority in the classroom (Duran et al., 2004; Fosnot, 1996; Mayer -Smith \& Mitchell, 1997); instructors must understand and be able to implement constructivist pedagogy. These authors' recommendations imply that if visions such as those advocated by constructivist educators are to become reality, we need to rethink the nature of teacher education efforts (e.g., to include the six mediatory experiences) as well as study the challenges inherent in change.

Having addressed the research questions in the previous sections, I move now to an assessment of the research. It is important for the status of our profession and to our integrity as teacher educators to assess critically any research, both reported and reviewed.

\section{Assessment of Research on Constructivist-Based Preservice Teacher Education}

In this section, I assess the type of research reviewed and evaluate it using criteria important to teacher education. The studies in this review fit Zeichner's (1999) description of new scholarship in teacher education; they are a rich and varied body of inquiry, relying on a broad range of questions and naturalistic methodologies respectful of the complexity of the questions and contexts. Most studies are conducted by those who work in teacher education; they are qualitative and use one view of research traditions and methodologies. This provides a rich description of efforts and a better understanding of constructivist teacher education. Most studies focus on understanding and describing characteristics of the phenomena; they make no claim to causality and do not suggest generalization beyond the contexts of the studies. Given that constructivist teacher education is relatively new to research, it is logical that qualitative research predominates; it helps to identify variables, describe processes and generate hypotheses for future research. More recently (since 2000), quantitative and mixed method studies are contributing to the conversation. Given the context of accountability of today, more quantitative studies are necessary. 
Only quality studies are included in this review and while there is always room for improvement in research methods, rather than critique the methodology, I evaluate the studies using a framework for assessing teacher education, recommended by Darling Hammond (2006). This framework is useful for conceptualizing the outcomes of teacher education programs and the research and assessment strategies for evaluating candidates' learning, practice, and effectiveness related to outcomes for children. Using her four-part framework to analyze the studies allows us to see the gaps in the research. She frames assessment of teacher education as (a) conceptualizing outcomes, (b) tracking candidate learning, (c) analyzing practice, and (d) researching graduate effectiveness.

\section{Conceptualizing Outcomes}

According to Darling Hammond (2006), "Assessing outcomes requires, first, a definition of what we expect teacher education to accomplish and influence in terms of candidate knowledge, skills and dispositions and, second, a means for measuring these things" (p. 123). This is one area that the studies of constructivist teacher education efforts fall short. While many efforts have clear goals, there is no agreed upon set of standards or outcomes related to what preservice teachers, accomplished in constructivist pedagogy, should know and do. The list of potential effects provided in Table 2 is a beginning point for discussing what outcomes are important.

\section{Tracking Candidate Learning}

Darling Hammond (2006) suggests that tracking candidate learning involves collecting perceptual data on their learning and what they believe they learned, and analyzing candidate performance (e.g., written assignments, pre-post tests). The majority of the studies reviewed fall in this category. Using surveys and interviews, often at different points in the programs, they provide data on pre-service teachers' perceived learning, sense of preparedness, and to a lesser extent, satisfaction with program. They also analyze candidate performance using pretests and post tests of candidate knowledge and assignments such as lesson plans, reflections, etcetera.

One omission in many of the studies is a detailed description of the instruments used in the research. Future research on reliable and valid instruments is critical to the understanding of the connection between constructivist teacher education and preservice teachers' knowledge and practice. Recent studies (Karadağ, 2007; Wooley, Benjamin, and Wooley, 2003) provide a foundation for this work.

\section{Analyzing Practice as an Outcome of Preparation}

This category relates to examining "whether and how they (preservice teachers) can apply what they have learned in the classroom" (Darling Hammond, 2006, p.129). Over half of the studies in this review include teaching events or portfolio-type artifacts (including video), indicating evidence of graduates' performance on authentic tasks. To a lesser extent, graduates are observed in their daily teaching practice. What is missing in this area of assessment relates to the first category, outcomes. Because outcomes are still in development, many observations are done without the use of protocols, such as checklists or rubrics designed to measure students' performance. In addition, with the exception of Levin (2003), there are few instances of longitudinal observations. 


\section{Research on Graduate Effectiveness}

As Darling Hammond (2006) notes, evidence of teachers' influence on children's learning is one of the most difficult and the most important areas of assessment. The complexities of teaching and the difficulties in securing data on children's performance make this a category that bears attention. Indeed, no studies in this review used pupil performance data to indicate a pre-service teachers' growth in knowledge or practice. Readers interested in effects on children may find the work of Project Construct (see Pfannenstiel \& Schattgen, 1997) and the Development Studies Center (see Battistich \& Solomon, 1995) useful. Of equal importance is a discussion on how we view childhood and methods for conducting research with children (Green \& Hogan, 2005). As we think more deeply about effects on children, we need to consider our assumptions of children, methods for researching children, and research on effects of constructivist practice on children.

Over the last two decades, we have amassed (and now synthesized) a wealth of knowledge and experience in constructivist work. The result is a richer articulation of constructivist teacher education and its effects. Findings from this review support Beck and Kosnik's (2006) proposal that constructivism "can provide crucial direction for preservice education" (p.7). Not only is it important that teacher education programs have philosophical or theoretical foundations (Zeichner \& Conklin, 2008) but also they need to be grounded in strong evidence. Based on the assessment, future research should include a variety of methodologies, develop adequate tools for measuring the effects of programs, investigate whether effects persist into the future practice of teachers, and examine effects on children. Also to be considered are three directions for research: studying the effects of graduate programs on in-service teachers, comparing effects of conventional and constructivist programs, and developing a model for constructivist teacher education programs, one that is theoretically grounded and research based. 


\section{References}

Al-Weher, M. (2004). The effect of a training course based on constructivism on student teachers' perceptions of the teaching/learning process. Asia-Pacific Journal of Teacher Education, 32(2), 169-184.

Anderson, D.,\& Piazza, J. (1996). Changing beliefs: Teaching and learning mathematics in constructivist preservice classrooms. Action in Teacher Education, 18(2), 51-62.

Battistich, V., \& Solomon, D. (1995, April). Linking teacher change to student change. Paper presented at the American Educational Research Association, San Francisco, CA.

Beck, C., \& Kosnik, C. (2001). From cohort to community in a preservice teacher education program. Teaching and Teacher Education, 17, 925-948.

Beck, C., \& Kosnik, C. (2006). Innovations in teacher education: A social constructivist approach. New York, NY: SUNY Press.

Black, A., \& Ammon, P. (1992). A developmental-constructivist approach to teacher education. Journal of Teacher Education, 43(5), 323-335.

Chen, S. (2001). Constructing a constructivist teacher education: A Taiwan experience. In Y. Cheng, K. Chow, \& K. Tsui (Eds.), New teacher education for the future: International perspectives (p. 261-290). Norwell, MA: Kluwer Academic Publishers.

Cheng, M., Chan, K, Tang, S., \& Cheng, A. (2009). Pre-service teacher education students' epistemological beliefs and their conceptions of teaching. Teaching and Teacher Education, 25, 319-327.

Condon, M. W. F., Clyde, J. A., Kyle, D. W., \& Hovda, R. A. (1993). A constructivist basis for teaching and teacher education: A framework for program development and research on graduates. Journal of Teacher Education, 44(5), 273-278.

Darling Hammond, L. (2006). Assessing teacher education. Journal of Teacher Education, 57(2), 120-138.

Dhindsa, H., \& Anderson, O. (2004). Using a conceptual change approach to help preservice science teachers reorganize their knowledge structures for constructivist teaching. Journal of Science Teacher Education, 15(1), 63-85.

Duran, L., Mc Arthur, J., \& Van Hook, S. (2004). Undergraduate students' perceptions of an inquiry-based physics course. Journal of Science Teacher Education, 15(2), 155-171.

Fosnot, C. T. (1996). Teachers construct constructivism: The center for constructivist teaching/teacher preparation project. In C. T. Fosnot (Ed.), Constructivism: Theory, perspectives and practices (p. 175-192). New York, NY: Teachers College Press.

Graham, P., Hudson-Ross, S., \& McWhorter, P. (1997). Building nets: Evolution of a collaborative inquiry community within a high school English teacher education program. English Education, 29(2), 91-129.

Greene, S. \& Hogan, D. (2005). Researching children’s experiences. London, England: Sage Publications.

Gunstone, R., Slattery, M., Baird, J., \& Northfield, J. (1993). A case study exploration of development in preservice teachers. Science Education, 77(1), 47-73. 
Hand, B., \& Peterson, R. (1995). The development, trial and evaluation of a constructivist teaching and learning approach in a preservice science teacher education program. Research in Science Education, 25(1), 75-88.

Jadallah, E. (1996). Reflective theory and practice: A constructivist process for curriculum and instructional decisions. Action in Teacher Education, 18(2), 73-85.

Karadağ, E. (2007). Development of the teachers' sufficiency scale in relation to constructivist learning: Reliability and validity analysis. Educational Sciences: Theory and Practice, 7(1), $165-175$.

Kilgore, K., \& Ross, D. (1993). Following PROTEACH graduates: The fifth year of practice. Journal of Teacher Education, 44(4), 279-287.

Kroll, L. R., \& Black, A. (1993). Developmental theory and teaching methods: A pilot study of a teacher education program. Elementary School Journal, 93, 417-441.

Lather, P. (1999). To be of use: The work of reviewing. Review of Educational Research, 69(1), 2-7.

Lesar, S., Benner, S., \& Habel, J. (1996, April). Preparing elementary education teachers for inclusive settings: A constructivist teacher education program. Paper presented at the Meeting of the American Educational Research Association, New York.

Levin, B. (2003). Case studies of teacher development. Mahwah, NJ: Lawrence Erlbaum and Associates.

Lincoln, Y., \& Guba, E. (1985). Naturalistic inquiry. Thousand Oaks, CA: Sage Publications.

Luera, G., \& Otto, C. (2005). Developing and evaluation of an inquiry based elementary science teacher education program reflecting current reform movements. Journal of Science Teacher Education, 241-258.

Magliaro, S., Murphy, S., Sawyers, J., Altieri, L., \& Nienkark, L. (1996, April). Reinventing teacher education: An examination of the social construction of learning in an elementary education program. Paper presented at the meeting ofthe American Educational Research Association, New York.

Marek, K., Laubach, T., \& Pederson, J. (2003). Preservice elementary school teachers'understandings of theory based science education. Journal of Science Teacher Education, 14(3), 147-159.

Mayer-Smith, J., \& Mitchell, I. (1997). Teaching about constructivism: Using approaches informed by constructivism. In V. Richardson (Ed.), Constructivist teacher education (p. 135-152). Washington, DC: Falmer Press.

Mosenthal, J. H., \& Ball, D. L. (1992). Constructing new forms of teaching: Subject matter knowledge in inservice teacher education. Action in Teacher Education, 18(2), 347-356.

O’Loughlin, M. (1992). Engaging teachers in emancipator knowledge construction. Journal of Teacher Education, 43, 347-56.

Parsons-Chatman, S. (1990, April). Making sense of constructivism in preservice: A case study. Paper presented at the annual meeting of the National Association for Research in Science Teaching, Atlanta, Georgia. 
Plourde, L., \& Alawiye, O. (2003). Constructivism and elementary preservice science teacher preparation: Knowledge to application. College Student Journal, 37, 1-10.

Pfannenstiel, J., \& Schattgen, S. (1997, March). Evaluating the effects of pedagogy informed by constructivism: A comparison of student achievement across constructivist and traditional classrooms. Paper presented at the American Educational Research Association, Chicago, IL.

Rainer, J., \& Guyton, E. (1999). From issues to action: Changing to a constructivist teacher education program. Journal of Professional Studies, 6(2), 23-33.

Rainer, J. (Ed.). (2002). Reframing teacher education: Dimensions of a constructivist approach. Dubuque, IA: Kendall-Hunt Publishers.

Rainer Dangel, J., \& Guyton, E. (2004). An emerging picture of constructivist teacher education. The Constructivist, 15(1), 1-35.

Richardson, V. (1997). Constructivist teacher education: Building a world of new understandings. London: Falmer Press.

Richardson, V. (2003). Constructivist pedagogy. Teachers College Record, 105(9), 1623-1640.

Sherman, A., \& MacDonald, L. (2007). Pre-service teachers' experiences with a science education module. Journal of Science Teacher Education, 18, 525-541.

Steele, D. (1994, April). Helping preservice teachers confront their conceptions about mathematics teaching and learning. Paper presented at the American Education Research Association, New Orleans, LA.

Stofflett, R., \& Stoddart, T. (1994). The ability to understand and use conceptual change pedagogy as a function of prior content learning experience. Journal of Research in Science Teaching, 31(1), 31-51.

Tatto, M. (1998). The influence of teacher education on teachers' beliefs about purposes of education, roles and practice. Journal of Teacher Education 49(1), 66-76.

Téllez, K. (2007). Have conceptual reforms in preservice teacher education improved the education of multicultural, multilingual children and youth? Teachers and Teaching: Theory and Practice, 13(6), 543-564.

Tillema, H. (2000). Belief change towards self-directed learning in student teachers: Immersion in practice or reflection on action. Teaching and Teacher Education, 16, 575-591.

Wideen, M., Mayer-Smith, J., \& Moon, B. (1998). A critical analysis of the research on learning to teach: Making the case for an ecological perspective on inquiry. Review of Educational Research, 68(2), p. 130-178.

Wood, T. (1995). From alternative epistemologies to practice in education: Rethinking what it means to teach and learn. In L. Steffe \& J. Gale (Eds.), Constructivism in education (p. 331340). Hillsdale, NJ: Lawrence Erlbaum Associates.

Wooley, S., Benjamin, J., \& Wooley, A. (2004). Construct validity of a self-report measure of teacher beliefs related to constructivist and traditional approaches to teaching and learning. Educational and Psychological Measurement, 64, 319-331. 
Zeichner, K. (1999). The new scholarship in teacher education. Educational Researcher 28(9), p. 4-15.

Zeichner, K., \& Conklin, H. (2008). Teacher education programs as sites for teacher preparation. In M. Cochran-Smith, S. Feiman-Nemser, J. McIntyre, \& K. Demers (Eds.), Handbook of research on teacher education. New York City, NY: Routledge. 


\section{Appendix}

\section{Table 1}

Research on Preservice Constructivist Teacher Education

\begin{tabular}{|c|c|c|}
\hline Study & Participants & Data Collection \\
\hline Al-Weher, M. (2004) & $\begin{array}{l}245 \text { (121 experimental group and } \\
124 \text { control group) elementary } \\
\text { students in three consecutive } \\
\text { semester science methods course }\end{array}$ & 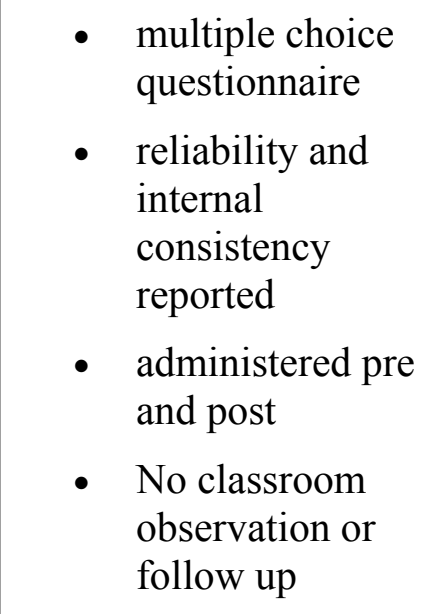 \\
\hline $\begin{array}{l}\text { Anderson, D. S. \& Piazza, J. A. } \\
\text { (1996) }\end{array}$ & $\begin{array}{l}\text { Undergraduate teachers in a one- } \\
\text { year sequence of mathematics } \\
\text { content and pedagogy courses for } \\
\text { elementary education }\end{array}$ & 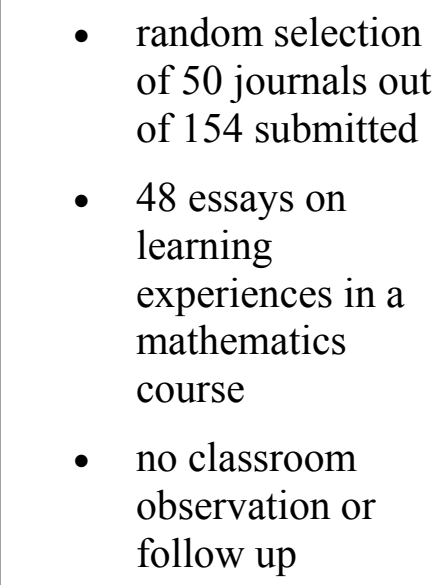 \\
\hline Beck, C. \& Kosnik, C. (2001) & $\begin{array}{l}\text { Student teachers over four years in } \\
\text { elementary program }\end{array}$ & $\begin{array}{l}\text { - } 4 \text { questionnaires } \\
\text { per year } \\
\text { administered over } \\
4 \text { years } \\
\text { - } \quad \text { interviews of } 6 \\
\text { student teachers } \\
\text { - } \quad \text { reflective writing } \\
\text { and student } \\
\text { assignments } \\
\text { - classroom }\end{array}$ \\
\hline
\end{tabular}




\begin{tabular}{|c|c|c|}
\hline & & observation \\
\hline Black, A. \& Ammon, P. (1992) & $\begin{array}{l}\text { Preservice teachers in the DTE } \\
\text { two-year post-baccalaureate } \\
\text { program (core seminars, methods } \\
\text { courses and practica) combining a } \\
\text { master of arts degree with the } \\
\text { credential for teaching in the } \\
\text { elementary grades }\end{array}$ & $\begin{array}{l}\text { - interview data and } \\
\text { weekly journal } \\
\text { writing } \\
\text { follow-up } \\
\text { interviews with } \\
\text { four graduates in } \\
3^{\text {rd }} \text { year of public } \\
\text { school teaching } \\
\text { no classroom } \\
\text { observation or } \\
\text { follow up }\end{array}$ \\
\hline Kroll, L. R. \& Black, A. (1993) & $\begin{array}{l}\text { Comparison study of three DTE } \\
\text { elementary graduates after } 2-5 \\
\text { years of teaching and three } \\
\text { traditionally prepared teachers } \\
\text { matched by grade level }\end{array}$ & 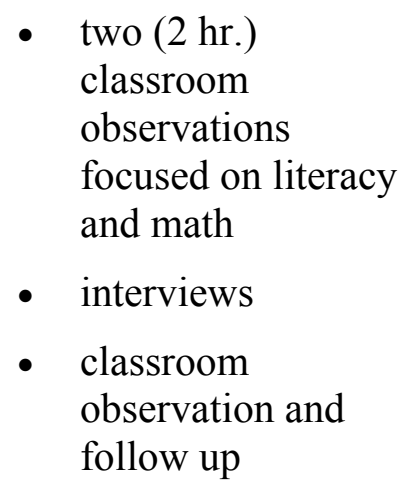 \\
\hline Levin, B. (2003) & $\begin{array}{l}4 \text { successful graduates from the } \\
\text { DTE program }\end{array}$ & $\begin{array}{l}\text { - a longitudinal (15 } \\
\text { yr.) study } \\
\text { - data includes six } \\
\text { interviews and } \\
\text { classroom } \\
\text { observations } \\
\text { - classroom } \\
\text { observation and } \\
\text { follow up }\end{array}$ \\
\hline Chen, S. (2001) & $\begin{array}{l}30 \text { elementary teachers (during } \\
\text { their practicum experience) }\end{array}$ & 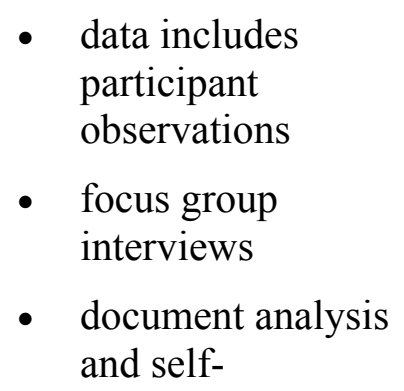 \\
\hline
\end{tabular}




\begin{tabular}{|c|c|c|}
\hline & & $\begin{array}{l}\text { evaluations } \\
\text { classroom } \\
\text { observation \& } \\
\text { follow up }\end{array}$ \\
\hline $\begin{array}{l}\text { Cheng, M. , Chan, K. , Tang, S. \& } \\
\text { Cheng, A. (2009) }\end{array}$ & $\begin{array}{l}\text { A study of } 288 \text { student teachers in } \\
\text { a four year elementary and } \\
\text { secondary program }\end{array}$ & $\begin{array}{l}\text { - } \begin{array}{l}\text { survey consisting } \\
\text { of two scales } \\
\text { (validation } \\
\text { reported) }\end{array} \\
\text { - } \begin{array}{l}\text { interviews with } 31 \\
\text { randomly-selected }\end{array} \\
\text { student teachers } \\
\text { no observation or } \\
\text { follow-up }\end{array}$ \\
\hline $\begin{array}{l}\text { Condon, M. W. F. , Clyde, J. A. , } \\
\text { Kyle, D. W. \& Hovda, R. A. } \\
\text { (1993) }\end{array}$ & $\begin{array}{l}\text { Three groups of } 36 \text { non-traditional } \\
\text { preservice teachers in a one-year } \\
\text { plus two summers K-4 program }\end{array}$ & $\begin{array}{ll}\text { - } & \text { structured } \\
\text { individual } \\
\text { interviews } \\
\text { - } & \text { no classroom } \\
\text { observation or } \\
\text { follow up }\end{array}$ \\
\hline $\begin{array}{l}\text { Dhindsa, H. \& Anderson, O. } \\
(2004)\end{array}$ & $\begin{array}{l}43 \text { preservice chemistry teachers } \\
\text { were educated using Cognitive } \\
\text { Strategy Instruction (CSI) }\end{array}$ & $\begin{array}{l}\text { - an essay on a } \\
\text { chemistry topic at } \\
\text { the beginning and } \\
\text { end of the program } \\
\text { - no classroom } \\
\text { observation or } \\
\text { follow up }\end{array}$ \\
\hline $\begin{array}{l}\text { Duran, L. , Mc Arthur, J. \& Van } \\
\text { Hook, S. (2004) }\end{array}$ & $\begin{array}{l}25 \text { middle grades science students } \\
\text { in a reform-based physics course }\end{array}$ & $\begin{array}{l}\text { focus groups and } \\
\text { semi structured } \\
\text { interviews } \\
\text { - } \quad \text { no classroom } \\
\text { observation or } \\
\text { follow up }\end{array}$ \\
\hline Fosnot, C. T. (1996) & $\begin{array}{l}30 \text { pre-service teachers and } 15 \\
\text { classroom teachers from five sites } \\
\text { Program includes a three-week } \\
\text { summer institute, fall and spring } \\
\text { semesters in a clinical fellowship }\end{array}$ & $\begin{array}{l}\text { - teachers' writing } \\
\text { (papers, journal } \\
\text { entries) to describe } \\
\text { the process of } \\
\text { constructing }\end{array}$ \\
\hline
\end{tabular}




\begin{tabular}{|c|c|c|}
\hline & year and a final summer institute. & $\begin{array}{l}\text { constructivism } \\
\text { no classroom } \\
\text { observation or } \\
\text { follow up }\end{array}$ \\
\hline $\begin{array}{l}\text { Graham, P., Hudson-Ross, S. \& } \\
\text { McWhorter, P. (1997) }\end{array}$ & $\begin{array}{l}\text { Preservice secondary English } \\
\text { teachers - } 8 \text { undergraduates and } 12 \\
\text { masters students. }\end{array}$ & $\begin{array}{ll}\text { - } & \text { interviews } \\
\text { - } & \text { synthesis papers, } \\
\text { teaching plans, } \\
\text { dialogue journals } \\
\text { - } & \text { video and audio } \\
\text { tapes of teaching } \\
\text { no classroom } \\
\text { observation or } \\
\text { follow up }\end{array}$ \\
\hline $\begin{array}{l}\text { Gunstone, R. , Slattery, M. , } \\
\text { Baird, J. \& Northfield, J. (1993) }\end{array}$ & $\begin{array}{l}13 \text { Preservice secondary science } \\
\text { students enrolled in a one year } \\
\text { science program. }\end{array}$ & $\begin{array}{ll}\text { - } & \text { individual and } \\
\text { group interviews }\end{array}$ \\
\hline Hand, B. \& Peterson, R. (1995) & $\begin{array}{l}135 \text { first year students in a science } \\
\text { course (from two semesters); four } \\
\text { students per class chosen at } \\
\text { random to participate during the } \\
\text { year }\end{array}$ & $\begin{array}{l}\text { - Instruments } \\
\text { included } \\
\text { interviews, journal } \\
\text { records, } \\
\text { questionnaires, } \\
\text { course evaluations } \\
\text { and observations } \\
\text { - No classroom } \\
\text { observation or } \\
\text { follow up }\end{array}$ \\
\hline Jadallah, E. (1996) & $\begin{array}{l}\text { Six students in a secondary } \\
\text { education course and 16-week } \\
\text { field experience }\end{array}$ & $\begin{array}{ll}\text { - } & \text { lesson plans \& } \\
& \text { videotaped lessons } \\
\text { - } & \text { reflective paper }\end{array}$ \\
\hline
\end{tabular}




\begin{tabular}{|c|c|c|}
\hline & & $\begin{array}{l}\text { - interviews } \\
\text { - classroom } \\
\text { observation and/or } \\
\text { follow up }\end{array}$ \\
\hline Kilgore, K. \& Ross, D. (1993) & $\begin{array}{l}\text { Four graduates of a elementary } \\
\text { program in their fifth year of } \\
\text { teaching }\end{array}$ & 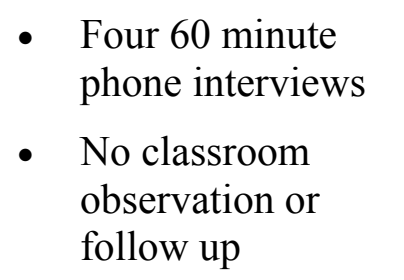 \\
\hline $\begin{array}{l}\text { Lesar, S. , Benner, S. \& Habel, J. } \\
\text { (1996) }\end{array}$ & $\begin{array}{l}\text { Elementary } 5^{\text {th }} \text {-year program } \\
\text { including } 32 \text { students and school } \\
\text { administrators and mentor } \\
\text { teachers from the internship site }\end{array}$ & 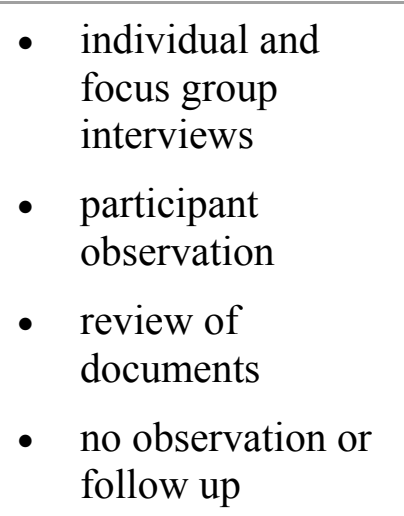 \\
\hline Luera, G. \& Otto, C. (2005) & $\begin{array}{l}285 \text { participants in a three course } \\
\text { elementary science program }\end{array}$ & $\begin{array}{l}\text { - MEAP to measure } \\
\text { content knowledge } \\
\text { - Science Teaching } \\
\text { Efficacy Behavior } \\
\text { Instrument }\end{array}$ \\
\hline $\begin{array}{l}\text { Magliaro, S. , Murphy, S. , } \\
\text { Sawyers, J., Altieri, L. \& } \\
\text { Nienkark, L. (1996) }\end{array}$ & $\begin{array}{l}\text { Eight of } 26 \text { first-semester seniors } \\
\text { in an elementary education student } \\
\text { teaching experience }\end{array}$ & $\begin{array}{l}\text { - } \text { individual and } \\
\text { focus group } \\
\text { interviews } \\
\text { - } \quad \text { field notes and } \\
\text { running records } \\
\text { - } \text { program } \\
\text { documentation } \\
\text { - Classroom } \\
\text { observation and/or } \\
\text { follow up }\end{array}$ \\
\hline $\begin{array}{l}\text { Marek, K. , Laubach, T. \& } \\
\text { Pederson, J. (2003) }\end{array}$ & $\begin{array}{l}61 \text { elementary education majors } \\
\text { from two courses }\end{array}$ & $\begin{array}{l}\text { - LCT scores and a } \\
\text { written narrative in } \\
\text { response to a }\end{array}$ \\
\hline
\end{tabular}




\begin{tabular}{|c|c|c|}
\hline & & $\begin{array}{l}\text { question about } \\
\text { students' } \\
\text { perceptions } \\
\text { - no classroom } \\
\text { observation or } \\
\text { follow up }\end{array}$ \\
\hline $\begin{array}{l}\text { Meyer-Smith, J. \& Mitchell, I. } \\
\text { (1997) }\end{array}$ & $\begin{array}{l}\text { Sixteen post-graduate preservice } \\
\text { teachers, assigned randomly }\end{array}$ & $\begin{array}{ll}\text { - } & \text { journal entries } \\
\text { - } & \text { weekly teaching } \\
\text { observations } \\
\text { - } & \text { interviews, and } \\
\text { out-of-class } \\
\text { discussions } \\
\text { - classroom } \\
\text { observation and/or } \\
\text { follow up }\end{array}$ \\
\hline Parsons-Chatman, S. (1990) & $\begin{array}{l}\text { Ten secondary preservice science } \\
\text { teachers in a one-year program } \\
\text { including } 10 \text { weeks of field }\end{array}$ & \\
\hline $\begin{array}{l}\text { Sherman, A. \& McDonald, L. } \\
(2007)\end{array}$ & $\begin{array}{l}31 \text { elementary teachers } \\
\text { participated in a ten week teaching } \\
\text { module focused on science }\end{array}$ & \\
\hline Steele, D. (1994) & $\begin{array}{l}19 \text { students in an elementary and } \\
\text { middle school math methods } \\
\text { course }\end{array}$ & \\
\hline Stofflett, R. \& Stoddart, T. (1994) & $\begin{array}{l}27 \text { students enrolled in two } \\
\text { sections of a science methods } \\
\text { course; one group received } \\
\text { content through traditional } \\
\text { methods and the other through } \\
\text { conceptual change methods }\end{array}$ & \\
\hline Tillema, H. (2000 & $\begin{array}{l}36 \text { student teachers from two } \\
\text { elementary programs participating } \\
\text { in weekly seminars for one year }\end{array}$ & \\
\hline
\end{tabular}




\section{Table 2}

Potential effects of short and long-term constructivist teacher education efforts (*italics denote change in classroom practice)

\section{A preservice teachers who experiences a short-term constructivist teacher education effort:}

\section{A preservice teachers who experiences a long-term constructivist teacher education effort:}

- distinguishes didactic from learner centered teaching approaches (MeyerSmith and Mitchell, 1997)

- demonstrates a familiarity with teaching for understanding

- $\quad$ espoused beliefs and demonstrated understanding consistent with constructivist ideas

- experiments with a range of procedures in their teaching, including probing the prior views of pupils, fluid discussions, pupils' examinations of their beliefs, role plays, and concept maps*

- perceives questions as essential to promote and challenge thinking (Jadallah, 1996)

- realizes the connection between motivation of children and active participation

- believes there was a need to relate content to pupils' interests and experiences

- recognizes the importance of examining pupils' understandings

- believes that methods of instruction should accommodate developmental characteristics of pupils and learning styles through sensory experiences

- $\quad$ are able to go beyond conceptual labels and clearly explain their reasoning

- introduces subject matter which caused students to experience cognitive
- changes their views on learning science (Hand and Peterson, 1995)

- increases their understanding of science topics

- develops ownership of ideas

- increases the importance of group work

- appreciates the role of discussion in the learning process

- views learner-centeredness as essential to teaching (Condon, et al., 1993)

- makes informed decisions based on observing children and action research

- develops a sense of efficacy that is more context specific than global

- makes a commitment to student learning (Kilgore and Ross, 1993)

- takes a view of themselves as learners

- espouses a view that teaching is complex and teachers have a responsibility in children's success

- $\quad$ shifts knowledge and beliefs about practice from a teacher and contentcentered to a student-centered approach (Graham, et al., 1997)

- deepens knowledge by adding personal meaning and adding research to their way of life

- develops a theoretical grounding for teaching in a more holistic and 


\section{dissonance}

- involves children in experiential learning

- includes higher-order thinking in lessons

- involves students in guided discovery lessons

- encourages active involvement of students in lessons

- $\quad$ builds lessons on students' interests

- begins to question the traditional view of what it means to know mathematics (Steele, 2001)

- sees mathematics as more a part of everyday life

- realizes there is more than one way to do math problems

- recognizes their own abilities as mathematical thinkers

- $\quad$ perceives their role as teachers to be that of a "guide"

- recognizes the importance of a risk free atmosphere for children to verbalize their ideas

- acquires positive learning behaviors and attitudes (Chen, 2001)

- develops collaborative and active learning habits

- learns to appreciate different ways of thinking and knowing

- increases their understanding of what promotes effective teaching and productive learning

- enhances their capability and sensitivity in reflection

- $\quad$ reduced the amount of lecturing and increased questioning and opportunities for students to discuss

- has significantly greater improvement in their scientific content knowledge than integrative way

- understands the range of sources and support needed and the value of a collaborative inquiry community to enhance understanding

- develops cognitive beliefs about mathematics pedagogy including the importance of manipulatives for enhanced learning, the use of group work, making mathematics make sense, student discussion, and learning and solving problems happens in diverse ways (Anderson and Piazza, 1996)

- $\quad$ are confident

- gains a deeper understanding by adding personal meaning

- enjoys learning

- values others' ideas and felt they had something to contribute

- improves conceptual understandings (Black and Ammon, 1992)

- uses strategies to construct understandings consistent with children's' developmental levels

- $\quad$ engages students in thought provoking activities

- guides students thinking toward better understanding

- $\quad$ organizes environment \& instruction for student interactions (Kroll and Black, 1993)

- $\quad$ makes extensive use of materials beyond textbooks

- $\quad$ supplements traditional assessments with observations for making evaluations

- focuses on learning content and process of collaboration

- uses manipulatives to allow for 
those in the traditional group (Stofflet \& Stoddart, 1994)

- gives qualitatively stronger pedagogical responses

- $\quad$ provides conceptually-based rationales for their pedagogy

- writes lesson plans that demonstrated coherent understandings of constructivist pedagogy

- finds they no longer needed textbooks in instruction and worksheets became tools for data collection

- $\quad$ uses constructivist pedagogy more consistently in practice, e.g., discovery activities and experimentation

- accesses new knowledge, elaborated on existing knowledge or both (Dhinsa and Anderson, 2004)

- increases their interconnectedness of ideas

- reconstructs their knowledge around more large organizing ideas

- carefully structures their logical arguments

- realizes the value of teaching through a conceptual change approach

- reports the importance of active involvement in reconstructing knowledge

- recognizes the need to tailor communication to meet the needs of learners

- recognizes constructivist methods were helpful for learning, but there was personal conflict in a constructivist atmosphere (Duran, et al., 2004)

- develops appreciation for inquiry-based methodology

- $\quad$ perceives workload as greater in constructivist course but valued a course discovery and foster understanding of relationships

- broadens their definitions of mathematics (Fosnot, 1996)

- realizes the importance of process, ownership, collaboration, and active, indepth learning.

- expands their views of teachers' roles to include providing support, guidance, and probing to encourage children's investigations

- experience intellectual development, specifically task related competencies (Gunstone, et al., 1993)

- enhance general aspects of intellectual competence (sense of self, professional purpose and personal awareness)

- understands how to facilitate students' learning and how to purposefully set up the learning environment (Levin, 2001)

- understands that student need to resolve their own disequilibrium

- $\quad$ sees the importance of academic and social worlds of students

- $\quad$ shifts the responsibility of learning to students

- establishes situations where students are responsible for making choice,

- establishes situations where students learn in a social context, e.g., work with peers and solve problems in groups

- beginning to encourage students' metacognition

- demonstrates understanding of inquirybased teaching approach (Marek, et al., 2003)

- $\quad$ sees the challenge of conceiving knowledge and learning in a new way (Lesar, et al., 1996) 
to meet their needs as science teachers

- needs relevant general education science courses

- Increased level of science knowledge (Sherman \& MacDonald, 2007)

- Increases level of confidence in teaching elementary science

- Improves attitude toward science teaching and learning
- sees the importance of quality of the relationships between faculty and students

- has an enhanced status as a professional during the internship year.

- Improves science content knowledge (Luera \& Otto, 2005)

- Improved efficacy towards teaching science

- Increases perceptions about constructivist teaching and learning, including role of the teacher and the learner in the learning process (AlWeher, 2004)

- Holds epistemological beliefs aligned with constructivist theories (Cheng, et al., 2009)

- Strongly believes that constructivist approach was the most effective teaching strategy

- Significantly espouses of a constructivist view

- Prefers learner-centered strategies

- Constructs beliefs about self-directed learning through immersion in practice followed by reflection (Tillema, 2000) 